\title{
Diabetes mellitus and the stomach
}

\author{
G.Stacher \\ Psychophysiology Unit, Department of Surgery, University of Vienna, Vienna, Austria
}

\begin{abstract}
Many patients with diabetes mellitus complain of early satiety and postprandial gastric fullness. In 1945, these symptoms were first found to result from a gastric motor dysfunction which makes the delivery of ingesta into the small intestine, the time of their absorption and the related blood-glucose rise unpredictable. Consequently, insulin or hypoglycaemic agents are administered at inappropriate time points and poor glycaemic control ensues. About $50 \%$ of patients with Type I (insulin-dependent) and Type II (non-insulin-dependent) diabetes mellitus are affected. Hyperglycaemia may play an important role in the disorder: gastric emptying was found to be slower in states of induced hyperglycaemia than in euglycaemia. However, significantly reduced blood-glucose concentrations after therapy readjustment were not associated with an increase in emptying rate. Prolonged hyperglycaemia could alter nerve metabolism and contribute to the development of neuropathy. Se-
\end{abstract}

verity of cardiovascular autonomic neuropathy, but not actual blood-glucose and glycated haemoglobin level, has been found to correlate with the degree of emptying impairment. Drugs enhancing gastric emptying could improve the coordination between insulin administration and the onset of nutrient absorption and thus glycaemic control. Disappointingly, trials to study the long-term effects of such drugs are scarce and their results predominantly negative. In conclusion, many diabetic patients have impaired gastric motor function which could contribute to poor glycaemic control. Evidence suggests that autonomic neuropathy is the main underlying factor. This review aims to offer a critical survey of all the data available at present on these topics. [Diabetologia (2001) 44: 1080-1093]

Keywords Diabetes, gastric motor function, gastric emptying, glycaemic control, hyperglycaemia, autonomic neuropathy, myopathy, symptoms, diagnosis, therapy.
Many patients with diabetes mellitus complain of early satiety and postprandial gastric fullness and discomfort. In 1945 symptoms of this kind were first found to be frequent in 125 patients with diabetic neuropathy and, in 5 patients, to be associated with a prolonged gastric emptying and intestinal transit of

Received: 14 March 2001 and in revised form: 23 May 2001

Corresponding author: Georg Stacher MD, Psychophysiologisches Laboratorium, Währinger Gürtel 18-20, A-1090 Wien, Austria, E-mail: georg.stacher@akh-wien.ac.at Abbreviations: ANP, Autonomic neuropathy; nNOS, neuronal nitric-oxide synthase barium sulphate [1]. Two years later the same investigators suggested that the disorder accompanied autonomic dysfunction on the basis of observations in another 30 patients with neuropathy [2]. In 1958, the term "gastroparesis diabeticorum" was coined [3]. A large number of publications have appeared since dealing with this complication, its potentially deleterious consequences in particular for glycaemic control, its diagnosis and the therapeutic options available. This review is aimed at critically evaluating the data published on diabetes and the stomach. 


\section{Impaired gastric motor function}

Gastric emptying. Since diabetic patients' feelings of early satiety and postprandial epigastric fullness were first attributed to delayed gastric emptying [1], the latter disorder was found to prevail in 30 to $60 \%$ of individuals with Type I (insulin-dependent) diabetes mellitus [4-9] and with Type II (non-insulin-dependent) diabetes mellitus [7, 10-15]. In most cases, the emptying of solid meal components is delayed [4, $9,12,16]$ with solids being retained mainly in the proximal stomach $[7,17]$. The emptying of liquids in diabetic patients was found to be normal $[4,9,12$, $16,18]$ or slower $[7,18,19]$ but also faster, mainly in the early phases of the disease, than in healthy individuals [6, 18, 20-23]. Delayed emptying could predispose to gastric bezoar formation: among 3247 patients having undergone oesophago-gastro-duodenoscopies, 14 had a bezoar and of these 7 had diabetes mellitus [24].

A controversy has arisen as to the gastric emptying in patients with Type II diabetes. Ten percent glucose solution has been found to be emptied more quickly in seven of nine patients with recently diagnosed Type II diabetes than in nine healthy subjects [25]. Of the control subjects all were non-Hispanic whites whereas among the patients seven were Hispanic, one Iranian and only one a non-Hispanic white. The ethnic origin cannot be ignored as the same group of authors reported that glucose was emptied significantly more quickly in healthy Hispanics than in healthy non-Hispanic whites [26]. Two further groups of researchers also reported a fast emptying of liquids in Type II diabetes. One study found that 14 of 20 diabetic patients emptied a liquid meal rapidly compared with 15, albeit younger, control subjects [27]. The other study found that 10 diabetic patients emptied a glucose solution, but not solids, more quickly than 12 healthy subjects [22]. In contrast, other investigators have reported that 16 patients with early Type II diabetes emptied glucose solution at a rate similar to 13 healthy subjects [28]. One study even found the emptying of solids to be enhanced: 8 patients with early Type II diabetes emptied a pancake together with a protein drink more quickly on average than 8 matched non-diabetic subjects [23]. However, a closer examination of this study's data reveals that emptying was more rapid in the first postprandial minutes only and much slower thereafter so that the patients' gastric contents at the end of recording were similar to the ones of the non-diabetic subjects.

Receptive relaxation of the fundus and antral motor activity. Fundic relaxation in response to a nutrient drink [29] or to soup ingestion [30] was revealed to be significantly less pronounced in diabetic patients than in control subjects. The fasting tone of the fundus, however, was found to be lower [29] and its com- pliance in response to intraluminal bag inflation greater than in healthy subjects [31]. In 20 Type I diabetic patients, soup was retained significantly more in the distal stomach than in 20 healthy subjects, i.e., the proximal-to-distal distribution ratio was significantly smaller [32]. A lower proximal gastric retention of liquid compared with healthy subjects was also found in another 20 diabetic patients, in particular in those with cardiovascular autonomic neuropathy (ANP) and symptoms of dyspepsia [18]. In 45 patients with cardiovascular ANP, markedly more of a semi-solid meal was retained in the distal than in the proximal stomach and the proximal-to-distal distribution ratio was significantly smaller than in 32 patients without ANP [33]. Ultrasonography found that the antrum was significantly wider after soup ingestion in Type I diabetic patients than in healthy individuals [34].

These findings are in agreement with observations made manometrically: the postprandial motor activity of the antrum in diabetic patients seems to be characterized by lower contraction amplitudes [17, 35] or a smaller motility index [36] than the one in healthy subjects. In the interdigestive periods of diabetic patients, a prolonged antral phase 2 and/or a less frequently occurring, or even no, phase 3 activity of the migrating motor complex has been observed [35-38] and phase 3 activity has been found to be absent in 6 of 7 patients with severe juvenile-onset Type I diabetes and gastroparesis [39]. A manometric study in the pylorus showed a longer duration of pre- and postprandial contractile activity in 24 diabetic patients with recurrent nausea and vomiting compared with 12 healthy subjects; 14 of the diabetic but only one of the healthy subjects also had episodes of prolonged and intense tonic contractions of the pylorus [40]. All of these peculiarities could contribute to delayed gastric emptying.

The gastric myoelectric slow wave activity as recorded by electrodes placed on the skin of the epigastrium, i.e., the electro-gastrogram, has been found not to differ between euglycaemic Type I diabetic patients with ANP and healthy subjects either in the fasting or in the postprandial state [41]. Furthermore, the electro-gastrogram did not differ between patients with Type I diabetes and healthy subjects during induced hyperglycaemia [42].

\section{Factors potentially underlying impaired gastric motility}

Hyperglycaemia. The nature of the changes that result in an abnormal gastric motor function in diabetic patients is still not clear. A crucial role has been ascribed to the prevailing blood-glucose concentrations. In healthy subjects, the rate of gastric emptying was found to be slower in states of induced hyperglycaemia [43-47]. In patients with Type I diabetes the rate of emptying was also found to be slower in in- 
duced hyperglycaemia than in euglycaemia $[5$, 47-55]. In Type II diabetic patients, the emptying of a liquid meal was significantly slower with increasing plasma-glucose concentration and the lag period observed with the emptying of a solid meal, i. e., the period before any ingesta are emptied, longer with higher than with lower plasma glucose [10]. In eight Type I diabetic patients with ANP, a pancake meal was emptied more slowly and the postprandial contractile activity of the antrum was lower in a state of induced hyperglycaemia than in a state of euglycaemia, whereas the emptying of a glucose solution was the same in both conditions [51]. Furthermore, the compliance of the proximal stomach to balloon distension was significantly greater in 10 patients with Type I diabetes during induced hyperglycaemia than during euglycaemia [52]. During insulin-induced hypoglycaemia, by contrast, eight Type I diabetic patients emptied both solids and liquids more quickly than during euglycaemia [53].

It is not clear, however, whether the gastric responses to acute alterations of blood glucose can be extrapolated to the emptying function under the condition of longer lasting hyperglycaemic states. A number of observations argue against long periods of raised blood-glucose concentrations having a decisive role. In patients with Type II diabetes and secondary failure to respond to oral hypoglycaemic therapy, the emptying of a semi-solid meal was recorded before the readjustment of treatment and one week thereafter. After therapy readjustment, all patients had markedly lower blood-glucose concentrations, both fasting and after meal ingestion but the emptying of the meal remained entirely unaffected [54]. In 21 patients with long-standing Type I diabetes, no correlation was found between the emptying of a solid meal and the preprandial plasma glucose [55]. No indications of a relation between emptying rate and preprandial blood-glucose concentrations were found either in studies with 30, 92 and 77 patients, respectively $[8,33,56]$. These observations are therefore in conflict with reports of a slow emptying after the induction of acute hyperglycaemia and argue against a major direct impact of naturally occurring prolonged hyperglycaemic states on gastric motor function.

As to be expected, a significant correlation exists between the rate at which a meal is emptied and the postprandial increase in blood glucose in healthy subjects [57] as well as in diabetic patients [8]: the slower the emptying, the more protracted the blood-glucose rise and, vice versa, the faster the emptying, the earlier and steeper the glucose rise. This highlights the importance of knowing the rate of delivery of ingesta into the small intestine, and thus the beginning of their absorption, for the treatment of diabetic patients.

Autonomic nervous dysfunction. Changes in neural function and polyneuropathy are found in practically all patients suffering from diabetes for more than a few years and can range from subclinical alterations of nerve conduction to life-threatening autonomic dysfunction [58]. Measurable signs of cardiovascular ANP were found in $27 \%$ of patients with Type I diabetes at the time of diagnosis [59] and in about $30 \%$ of patients who had had diabetes for 10 to 15 years [60]. The prevalence of ANP increases with the duration of the disease [59]. The 10-year survival rate of patients with symptoms of ANP, such as diarrhoea, postural hypotension, gustatory sweating and abnormal heart-rate variability, is markedly lower than the one of asymptomatic subjects both with and without abnormal heart-rate variability [61].

Neuropathy could evolve from prolonged hyperglycaemic states [62], which result in an activation of the polyol pathway, a tissue accumulation of sorbitol and fructose, a myoinositol deficiency and an altered nerve metabolism, but also from a decreased nitricoxide production and a deficiency in neurotrophic growth factors [63-66]. Changes in nerve metabolism could reduce the density of nerve fibres [67] and lead to a length-related neuropathy of the dying-back type $[67,68]$ and multifocal ischaemic lesions mainly affecting microvessels [69-71]. By contrast, the absence of prolonged hyperglycaemic states was observed to be associated with a low incidence of neuropathy [72]. In the Diabetes Control and Complications Trial (DCCT) [73], the occurrence of clinical neuropathy over a time span of 6.5 years was found to be $60 \%$ lower in those of the 1441 patients who received intensive therapy aimed at maintaining blood-glucose concentrations close to the normal range than in the patients on conventional therapy. Accumulating evidence suggests that the factors involved in the development of neuropathy are interrelated [66].

In mouse models of Type I diabetes, i.e., in mice with streptozotocin-induced and genetic diabetes (non-obese diabetic mice), immuno-histochemistry showed a marked reduction in neuronal nitric-oxide synthase (nNOS) protein expression not resulting from a loss of myenteric neurons. The fact that other neuronal markers, such as synaptophysin, Map-2 and vasoactive intestinal polypeptide, were not significantly lower indicates a selective loss of nNOS expression. In these mice, the emptying of dextrose solution was found to be markedly delayed and the non-adrenergic non-cholinergic relaxation of the pylorus impaired $[74,75]$. These changes resemble the defects found in mice with a deletion of the $n N O S$ gene ( $n N O S$-/-) or treated with a nNOS inhibitor. As both the nNOS expression and pyloric function could be restored to normal by insulin treatment, gastropathy in diabetic mice seems to result from a reversible down regulation of nNOS expression. By contrast, the delay in emptying was not reversed after a 12-h period of insulin-induced normoglycaemia, which indicates that hyperglycaemia was not the cause of im- 
paired emptying $[74,75]$. The impaired receptive relaxation of the fundus $[18,29,30,32-34]$ was also found to result mainly from an impaired nNOS expression [76].

Another recent study showed that genetically nonobese diabetic mice developed not only delayed gastric emptying but also an impaired electrical pacemaking and reduced motor neurotransmission in the stomach [77]. These changes have been related to a greatly reduced number of interstitial cells of Cajal in the tunica muscularis of the corpus and antrum, cells which generate the gastric electrical pace-maker activity and mediate motor neurotransmission [78]. Furthermore, the close associations between these cells and the enteric nerve terminals found in healthy animals were infrequent in diabetic mice [77]. A markedly lower number of interstitial cells of Cajal have also been found in sections from jejunal tissue that appeared normal of a Type I diabetic patient with gastroparesis. The sections showed a reduced presence of mediators of inhibitory neurotransmission, i.e., of vasoactive intestinal polypeptide, pituitary adenylate cyclase-activating polypeptide and nNOS, on the one hand and larger amounts of substance $\mathrm{P}$, a mediator of excitatory neurotransmission, on the other [79] suggesting that a loss of interstitial cells of Cajal and changes in neurotransmission could play a key role in the pathogenesis of diabetic gastroparesis.

Evidence suggests that immunological factors could play a part in the development of ANP. Phospholipid autoantibodies have been found to be present more frequently in the sera of diabetic patients and to correlate with the extent of neuropathy; they could therefore be indicative of ongoing damage to nerves [80]. In patients with Type I diabetes, autoantibodies to nervous tissue structures, in particular anti-sympathetic ganglia and anti-vagus nerve antibodies, have been found to be associated with symptomatic ANP [81]. Autoantibodies against autonomic nervous structures have been found in adolescents with a mean Type I diabetes duration of 6.8 years, who had no signs or symptoms of ANP [82]. Autoantibodies to vagal nerve, cervical ganglia and adrenal medulla targets have been detected frequently in Type I diabetic patients but rarely in healthy blood donors [83].

Although some investigators failed to find clear associations between autonomic nervous and gastric dysfunction $[21,84,85]$ and others found that ANP had a poor predictive value for motor dysfunction [14], a number of studies have shown that the gastric emptying of liquid $[5,90]$, solid $[5,6,56,86,87,90$, 91], semi-liquid [88] and semi-solid [8, 42] ingesta as well as of radiopaque markers ingested with a solidliquid meal [89] was slower in individuals with cardiovascular ANP than without. The severity of cardiovascular ANP has also been reported to correlate sig- nificantly with the degree of gastric motor impairment $[5,6,56,87,90]$. Twenty patients with severe cardiovascular ANP emptied an omelette significantly more slowly than 12 patients with mild and 29 without ANP [91] and a significant relation between emptying rate and severity of ANP was also found in 92 Type I diabetic patients [8].

Not only the emptying function but also antroduodenal motor activity, gastric secretory function as well as gastrooesophageal reflux activity could all be affected by ANP. In diabetic patients with both early and definite cardiovascular ANP, the frequency of antroduodenal coordination as well as the frequency and duration of retrograde transpyloric flow episodes following antegrade flow were found to be significantly lower than in healthy subjects [92]. An investigation in 19 diabetic patients showed that those with cardiovascular ANP had a significantly lower gastric secretory response to sham feeding than patients without ANP, although basal and pentagastrin-induced acid secretions did not differ between the two groups [93]. A reduced secretory response to sham feeding has been suggested to be indicative of vagal neuropathy [94]. A study in Type I diabetic patients without symptoms or a history of upper gastrointestinal disease showed that no less than 12 of 31 patients with cardiovascular ANP but only 2 of 19 without cardiovascular ANP had an abnormal 24-h gastrooesophageal reflux activity and that the prevalence of the latter was much higher in patients with ANP than the one to be expected in healthy subjects [95]. The increased prevalence of abnormal reflux can probably be ascribed, at least in part, to the impairment of gastric emptying affecting a large proportion of patients.

Information on the development of ANP and gastric motor and secretory dysfunction over time is scarce. An investigation carried out in 32 patients with Type I diabetes over a 5-year period showed a significant increase in autonomic nervous as well as somatosensory dysfunction [96]. A 10-year follow-up study in 133 Type II diabetic patients showed a massive rise in cardiovascular ANP, which was not related to a deterioration of peripheral neuropathy [97, 98]. In 57 patients with Type I diabetes of more than 10 years' duration, who were studied at the beginning and the end of a 9-year period, the prevalence of cardiovascular ANP increased together with gastroparesis [99]. The association between ANP and impaired gastric motor and/or secretory function could be closer than thought as there is still no validated technique available to assess gastrointestinal autonomic nervous function.

Gastrointestinal myopathy. Some evidence suggests that impaired gastric motor function could also be due to an intestinal myopathy or to a concurrence of myopathy and a dysfunction of the neural structures 
governing motor and secretory activity. A post-mortem study in - alas - only five patients with Type I diabetes found polyneuropathy including inflammatory changes in autonomic ganglia and unmyelinated nerves as well as a severe loss of myelinated fibres in the vagal nerves and in the sympathetic trunks as well as a focal hyaline degeneration of the smooth muscle in many viscera [100]. In contrast, no morphological abnormalities in either the gastric wall or the abdominal vagus were found in 16 patients with long-standing diabetes [101]. In an animal model resembling human Type I diabetes, i. e., in spontaneously diabetic biobreeding/Worcester rats, the response of gastric circular muscle strips to direct myogenic stimulants was found to be significantly impaired [102]. The fact that the acetylcholine release from the animals' gastric myenteric plexus in response to transmural electrical stimulation and that the voltage-dependent calcium-ion entry into the muscle strips were intact suggests an impairment of smooth muscle function resulting from an altered intracellular signal transduction. In four patients with longstanding Type I diabetes and gross ANP, who had undergone partial gastrectomies as a last remedy for their intractable vomiting, histopathology of the removed parts of the stomach showed evidence of smooth-muscle degeneration and fibrosis with eosinophilic inclusion bodies ("M-bodies"). This suggests that the patients' gastroparesis was due to a myopathy rather than to denervation, because denervation does not cause intestinal smooth-muscle atrophy [103].

\section{Diagnostic approaches}

History taking. How does a physician find out whether a diabetic patient complaining of early satiety, epigastric fullness, belching and vomiting or devoid of any of these symptoms but with therapy-resistant poor glycaemic control has an impaired gastric motor function? The indispensable first step, a thorough history taking, can yield important clues. The occurrence and course of symptoms and their relation to the composition, volume, frequency and timing of meals needs to be ascertained. Eating habits, self-imposed dietary restrictions or peculiarities, appetite, stool frequency and consistency as well as patterns of alcohol intake need to be understood and information gained on undergone operations, traumata and illnesses, in particular of peptic ulcer and gastrooesophageal reflux disease and other gastrointestinal affections. Furthermore, the presence of malignancies and electrolyte imbalances has to be explored.

Symptoms. Some authors have highlighted the paucity of symptoms associated with slow gastric emptying or the poor relation between such symptoms and the emptying rate [5]. One study suggested that this supposed symptom paucity resulted from an impaired visceroception [104]. This explanation is supported by the observation made in 89 patients with Type I diabetes and 481 with Type II diabetes as well as in 635 healthy subjects that the occurrence and spectrum of gastrointestinal symptoms in the three groups did not differ [105]. Similar observations were made in a study carried out in 1262 residents of Olmsted County, Minnesota, in which symptom questionnaires were sent to patients with Type I and with Type II diabetes as well as to two age-stratified and sex-stratified random samples of non-diabetic subjects [106]. The prevalence of most symptoms referable to the upper gastrointestinal tract, in particular dyspepsia, nausea and vomiting, was found to be similar in subjects with and without diabetes.

There have been studies, however, which reported that diabetic patients with slow gastric emptying complained of a greater number of symptoms referable to the gastrointestinal tract than patients with normal emptying [6] and that symptoms of dyspepsia predicted, in a linear regression model, delayed emptying [90]. More recently it was observed that upper gastrointestinal symptoms were significantly more prevalent in 110 patients with long-term Type I diabetes than in 210 control subjects matched for age and sex; moreover, patients with $\mathrm{HbA}_{1 \mathrm{c}}$ values in the highest quartile had significantly more symptoms than the others [107]. In one of two further studies with similar results, 489 diabetic patients reported a significantly greater number of gastrointestinal symptoms than 200 matched healthy subjects. Further, patients with neuropathy had significantly more symptoms than those without neuropathy and their symptoms correlated only with neuropathy and not with metabolic control or any other complications [108]. The second study carried out in 483 diabetic patients and 422 matched subjects, found that the patients had a significantly higher overall prevalence and greater number of upper gastrointestinal symptoms than the control subjects [109]. Thus, a paucity of symptoms hinting at impaired gastric motor function does not seem to be characteristic of diabetic patients

\section{Assessment of gastric emptying}

What are the means available to assess the net effect of gastric motor function, the emptying of the ingesta?

Fluoroscopy. A fluoroscopic examination can provide information about obstructive lesions, food retained even after a prolonged fast and the stomach's shape and size. If the stomach is hypotonic, it will lengthen with the intake of barium sulphate and the antrum will appear funnel shaped. Although gastric 
contractions and the transport of barium into the small intestine can be detected, quantitative information cannot be obtained.

Radiopaque markers. Spheres of a diameter of $1.4 \mathrm{~mm}$ and a specific gravity of about 1 are emptied at a rate similar to radiolabelled liver [110], whereas larger spheres tend to be retained until the occurrence of a phase 3 of the interdigestive migrating motor complex [111]. However, even small spheres are not suited for assessing emptying as the feedback mechanisms, which depend on receptors responding to the composition of the chyme delivered to the small intestine, do not come into play $[112,113]$.

Scintigraphy. Scintigraphic techniques are, at present, the ones best suited and documented for clinical use. Ideally, the measurement of the emptying of solid and liquid meal components, which can be different, is done simultaneously. However, as meals comprise mainly solids and solids tend to be retained over prolonged periods of time, the assessment of the emptying of liquids might not be absolutely necessary. When gamma-scintillation-camera time is scarce, the use of a semi-solid meal is advisable. A semisolid meal is emptied, after a very short lag phase during which the first part of the ingesta is ground down by the antrum and thus becomes ready for delivery to the duodenum, at a similar rate to that of solids after the lag phase $[114,115]$. Consequently, the time needed for an investigation is considerably shorter than for a solid meal. The meal employed should be palatable and include more than $1260 \mathrm{~kJ}$, that is, enough to challenge feedback regulation by the small intestine. The blood-glucose concentration immediately before the recording should be measured as it might influence the emptying rate. Scintigraphy also allows the distribution of the meal between fundus, corpus and antrum at various time points after ingestion to be assessed. Techniques have also been developed for evaluating the amplitude and propagation velocity of antral contractions [114-118]. The radiation burden is less than half of the burden resulting from a plain radiography of the abdomen, so that the application of the technique for children and repeat studies to evaluate treatment effects are feasible.

Tracer techniques. These techniques record, at given time points after the consumption of a labelled meal, the concentrations of a tracer substance in the breath or blood under the assumption that it is rapidly absorbed from the small intestine but not the stomach, that its disappearance from the blood is constant and that there is little or no tracer recirculation from other bodily pools. The emptying of a solid meal can be measured after mixing it with octanoic acid labelled with the radioactive ${ }^{14} \mathrm{C}$ or better the stable isotope ${ }^{13} \mathrm{C}[57,119]$.
Real-time ultrasonography. Several sonographic techniques have been developed to record emptying indirectly. One assesses the volume contained in the antrum as indicated by the cross-sectional area at time points before and after the ingestion of a liquid, semi-solid, solid or solid-liquid meal [120-125]. The emptying time is defined as the point at which the antral volume has returned to its preprandial value. Another procedure determines the volume of the entire stomach, at regular intervals after a liquid meal, by sampling cross sections at multiple sites [126]. However, volume determination is difficult because of the stomach's complex configuration and the unavoidable presence of gas in the fundus and superimposed viscera. A less time-consuming approach is to record the emptying and the intragastric distribution of a liquid meal using sagittal and oblique frontal sections of the proximal and the distal stomach, respectively [127]. Superior in accuracy and precision to the above-mentioned procedures is a technique which permits, although not in real time, the three-dimensional assessment of the intragastric distribution and emptying of a soup meal [128]. However, it has not yet been validated against scintigraphy and using it with a solid meal could be difficult.

More sophisticated techniques such as impedance epigastrography [129], impedance tomography [15] and magnetic resonance imaging [130] have also been shown to reliably record gastric emptying. At the time being, they could be useful in the research setting but cannot be recommended as tools in clinical practice.

\section{Treatment of impaired gastric emptying}

\section{Dietary modification}

Emptying delays of a lesser extent could be combated by advising the patient to eat 6 to 8 small meals per day instead of adhering to the classical meal sequence [131]. As semi-solids are emptied more readily than solid ingesta, the meals should be of a soft consistency [132]. Controlled trials in the efficacy of such dietary modifications, however, are lacking.

To improve glycaemic control, various diabetes associations recommended diets high in fibre and complex carbohydrates and low in fat. An open crossover study in 10 patients with Type I diabetes showed that the consumption of a high-fibre and low-carbohydrate diet for 4 weeks enhanced the peripheral glucose disposal and decreased the basal insulin requirements but did not alter glycaemic control [133]. In 15 patients with Type II diabetes, the addition of $15 \mathrm{~g}$ guar gum to the daily diet for 48 weeks resulted in an improvement of long-term glycaemic control, postprandial glucose tolerance and lipid concentrations [134]. The effect of an increased fibre intake was also 
evaluated in a randomised crossover study: 13 patients with mild Type II diabetes ate, for 6 weeks, two diets of identical macronutrient and energy content supplemented with either $8 \mathrm{~g}$ of soluble and $16 \mathrm{~g}$ of insoluble fibre or $25 \mathrm{~g}$ soluble and $25 \mathrm{~g}$ insoluble fibre. After the high-fibre diet, fasting and postprandial blood-glucose concentrations as well as the mealevoked insulin concentration were significantly lower than after the moderate-fibre diet but there was only a tendency towards better glycaemic control [135].

The mechanisms involved in the generation of the above-mentioned effects are not known. Studies in small numbers of healthy individuals suggest that meals rich in fibre are emptied more slowly from the stomach than meals with a low fibre content [136, 137]. Accordingly, in 12 obese patients with poorly controlled Type II diabetes, a supplementation of the diet with $20 \mathrm{~g}$ guar gum and $10 \mathrm{~g}$ wheat bran for two months resulted in a slowing of the emptying of solids and liquids and an improvement of metabolic control [138]. In another study, seven Type II diabetic patients emptied a meal supplemented with $5 \mathrm{~g}$ sodium alginate significantly more slowly than a fibrefree meal and the increases in their postprandial blood glucose were lower [139]. However, not the amount but the nature of the fibre, in particular its particle size, seems to play the critical role: in 12 healthy subjects, a rice pudding was emptied more slowly when coarse bran was added and not fine bran [140]. Furthermore, the addition of ispaghula husk with a particle size smaller than $0.2 \mathrm{~mm}$ or of plastic particles 1 to $2 \mathrm{~mm}$ in size did not slow the emptying of the rice pudding, whereas the addition of unprocessed bran 2 to $5 \mathrm{~mm}$ in particle size resulted in a significant slowing [141]. Thus, patients with fast emptying could benefit from a high intake of coarse bran but it does not seem likely that a high-fibre diet is beneficial for patients with delayed emptying.

\section{Treatments aimed at accelerating gastric emptying}

Drugs which enhance gastric emptying might improve the coordination between the time point at which the ingesta reach the small intestine and thus the onset of absorption on the one hand and of insulin administration on the other. In fact, a series of acute and open-label investigations or in the effects of such agents suggested that the employment of such drugs could be beneficial. Controlled trials, however, in particular controlled trials on long-term effects, are scarce and their results mostly negative.

Metoclopramide. Metoclopramide acts as an antagonist at dopamine ${ }_{2}$ - but also at 5-hydroxytryptamine ${ }_{3}$ receptors in the myenteric plexus. Its acceleratory effect on gastric emptying is thought to be due to a facilitation of cholinergic excitatory neurotransmission, possibly through an agonistic effect at 5-hydroxytryptamine ${ }_{4}$-receptors $[142,143]$.

Acute studies in the effects of metoclopramide yielded ambiguous results. A solid-liquid meal was emptied faster after $10 \mathrm{mg}$ metoclopramide intramuscularly than at a baseline recording by only 7 of 12 diabetic patients [144]. In a crossover double-blind study in 9 patients, $10 \mathrm{mg}$ metoclopramide intravenously (i.v.) enhanced the emptying of a doughnut breakfast containing radiopaque markers markedly but not significantly [145]. In an open-label investigation in 10 diabetic patients with cardiovascular ANP and symptoms of slow emptying an i.v. bolus of metoclopramide but also a regimen of $10 \mathrm{mg}$ metoclopramide orally four times a day (q.i.d.) for 2 weeks accelerated the emptying of solids, so that the latter was similar to the one of 10 non-diabetic patients [16]. In another open-label study in patients with slow emptying, $10 \mathrm{mg}$ metoclopramide i.v. and orally accelerated the emptying of a liquid meal, whereas $10 \mathrm{mg}$ metoclopramide orally concluding the administration of $10 \mathrm{mg}$ three times a day (t.i.d.) for one month failed to enhance emptying [19].

Two placebo-controlled double-blind studies evaluated the effects of metoclopramide administered for longer periods of time (Table 1). In a crossover trial, 8 of 9 Type I diabetic patients with gastroparesis emptied a mixture of orange juice and normal saline faster after 3 weeks of metoclopramide than before, whereas after placebo this was the case in 5 of 9 patients. However, all patients had less or no vomiting while on metoclopramide but continued to vomit when on placebo [146]. A crossover trial in 19 patients also showed that metoclopramide for 8 weeks had the same effect on the emptying of solids and liquids as placebo [20].

Domperidone. Domperidone acts as an antagonist at dopamine $_{2}$-receptors in the myenteric plexus [147]. Because domperidone does not penetrate into the central nervous system, its effects are confined to the periphery. An acute double-blind placebo-controlled trial showed that $10 \mathrm{mg}$ domperidone i.v. enhanced the emptying of a semi-solid meal in all of six diabetic patients with symptomatic gastroparesis but had no effect in six healthy subjects [148]. In a double-blind study in 12 Type I diabetic patients with cardiovascular ANP, a single oral dose of $40 \mathrm{mg}$ domperidone accelerated the emptying of both solids and liquids significantly more than placebo did [149]. Subsequent to the acute study, the patients took $20 \mathrm{mg}$ domperidone t.i.d. for 35 to 51 days. After that period and a single dose of $40 \mathrm{mg}$ domperidone, the emptying of solids was the same as for the placebo in the study's acute phase, but liquids were emptied faster [149]. No effects on the emptying of solids were observed either in six Type I diabetic patients who had taken $20 \mathrm{mg}$ domperidone q.i.d. for 6 months [150]. 
Table 1. Placebo-controlled, double-blind long-term trials carried out to assess drug effects on gastric emptying in diabetic patients. q.i.d., four times a day; t.i.d., three times a day

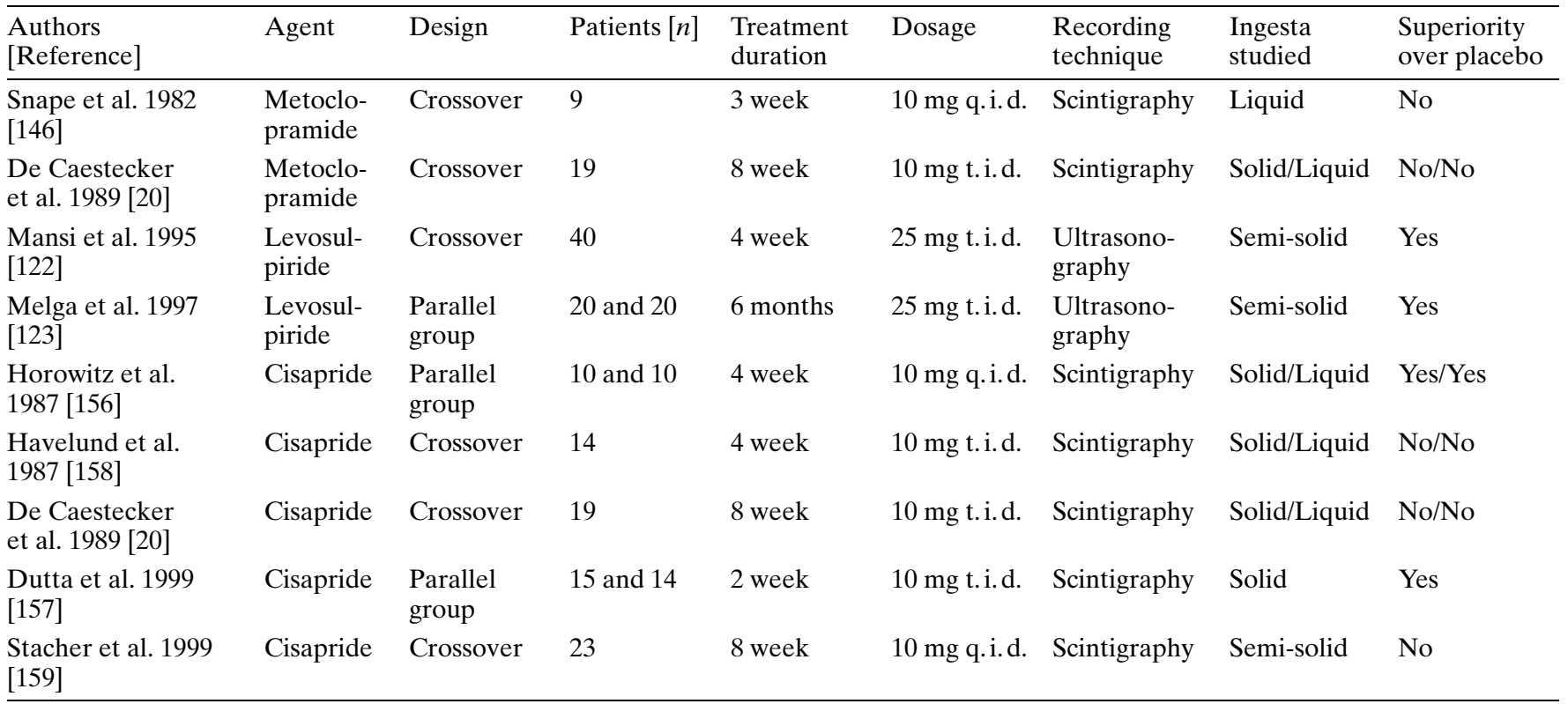

One study investigated the effects of a singlemasked oral medication of $20 \mathrm{mg}$ domperidone q.i.d. for 4 weeks on symptoms indicative of gastroparesis. Of 287 diabetic patients, 208 responded with a decrease in symptom frequency and intensity. These 208 individuals were included in a 4-week double-blind withdrawal study, during which they received either $20 \mathrm{mg}$ domperidone q.i.d or placebo. Patients on placebo became significantly more symptomatic than those on domperidone [151].

Levosulpiride. Levosulpiride, the levorotatory enantiomer of sulpiride, acts as a selective antagonist at dopamine $_{2}$-receptors in the myenteric plexus [152]. Its effects were evaluated in two double-blind placebo-controlled investigations, a crossover study with 4-week and a parallel-group study with 6-month treatment periods $[122,123]$. In both studies, levosulpiride significantly accelerated emptying (Table 1 ).

Cisapride. Cisapride is thought to promote gastric emptying mainly by acting as a partial agonist at 5-hydroxytryptamine $_{4}$ receptors in the myenteric plexus and thereby facilitating cholinergic excitatory neurotransmission [142, 143]. In uncontrolled singledose investigations in diabetic patients, the agent was found to accelerate emptying [145, 153], but the results of studies extending over longer periods of time have been ambiguous [154, 155].

Placebo-controlled double-blind trials on the longterm effects of cisapride are few and the numbers of patients included often small (Table 1). In one study, 20 patients with Type I diabetes emptied solids and liquids significantly faster after an oral dose of cisa- pride than after placebo. A subsequent parallelgroup trial in the same patient group showed that the 10 individuals who had taken cisapride over 4 weeks emptied solids and liquids significantly faster than the 10 who had taken placebo [156]. In a parallel-group double-blind trial, 15 gastroparetic patients who had received cisapride for a fortnight emptied a rice cake significantly faster than at a basal recording, whereas there was no significant change in 14 patients who had received placebo [157]. Two double-blind crossover trials in 14 and 19 patients showed that cisapride for four [158] and 8 weeks [20], respectively, did not affect gastric emptying and symptoms any more than placebo. A double-blind crossover trial in 23 patients with Type I diabetes showed that the effects of cisapride administered over 8 weeks on the emptying of a semi-solid meal, glycaemic control and symptoms were the same as for patients on placebo [159].

Erythromycin. The macrolide antibiotic erythromycin mimics the effects of the polypeptide motilin on gastrointestinal motor activity probably by binding to motilin receptors [160]. In an acute double-blind crossover investigation in 10 Type I diabetic patients with gastroparesis, $200 \mathrm{mg}$ erythromycin i. v., but not placebo, significantly accelerated the emptying of both solids and liquids [161]. After a subsequent 4week period, during which all patients received $250 \mathrm{mg}$ erythromycin orally t.i.d., the acceleratory effect was much less [161]. In an open study on 12 diabetic patients with gastroparesis, the emptying of solids and liquids was enhanced not only by i.v. erythromycin but also by the agent's oral medication for 3 weeks [162]. A placebo-controlled double-blind 
crossover study in 10 Type I diabetes patients with gastroparesis showed that single oral doses of 250 and $1000 \mathrm{mg}$ erythromycin significantly accelerated the emptying of a solid meal [163]. In 12 Type I diabetic patients, the antroduodenal motor activity as recorded by an ambulatory manometric technique was improved, both in the fasting state and following a high-caloric meal, after $250 \mathrm{mg}$ erythromycin t.i.d. over 2 weeks [164].

\section{Treatments aimed at delaying gastric emptying}

The reports of an accelerated emptying of liquids in patients with Type II diabetes [22, 25, 27] suggested that agents which slow emptying could delay and reduce the postprandial blood-glucose increases and thus improve glycaemic control [165].

Cholecystokinin. In healthy subjects, both i.v. infusions of physiological doses of cholecystokinin octapeptide and the stimulation of endogenous cholecystokinin release, as evolving after the ingestion of lipid-containing long-chain triglycerides, were shown to delay emptying and to reduce postprandial plasma-glucose and insulin increases [166]. Similarly, in seven patients with Type II diabetes and accelerated emptying, cholecystokinin octapeptide not only delayed the emptying of glucose solution but also reduced the ensuing blood-glucose increase [165]. In six Type II diabetic patients, the trypsin/chymotrypsin inhibitor POT II, which increases plasmacholecystokinin concentrations, delayed the emptying of a glucose-protein solution and reduced the increase in postprandial plasma glucose [167].

Glucagon-like peptide-1. This peptide stimulates insulin secretion by improving the insulinotropic action of glucose and by suppressing glucagon secretion, which leads to an inhibition of hepatic glucose production and a decrease in blood-glucose concentrations [168]. In nine healthy subjects and eight patients with poorly controlled Type II diabetes, i.v. infusions of the peptide delayed the emptying of a liquid meal and reduced the postprandial plasma-glucose increase [169, 170]. In a double-blind crossover study in six patients with poorly controlled Type II diabetes, glucagonlike peptide- 1 injected subcutaneously (s.c.) over 3 weeks reduced the postprandial plasma-glucose increase significantly more than did placebo [171].

Amylin. The peptide amylin is co-secreted with insulin by the pancreatic beta cells in response to nutrient stimuli and is deficient in patients with Type I diabetes and elevated in patients with early Type II diabetes; its main action is to inhibit postprandial glucagon secretion [172]. In Type I diabetic patients, the amylin analogue, pramlintide, administered s.c. for a fortnight reduced postprandial as well as 24-h plasma-glucose concentrations [173, 174]. Two large placebo-controlled double-blind parallel-group trials showed that pramlintide injected t.i.d. and q.i.d. over 4 weeks improved glycaemic control in patients with Type I diabetes [175] and in patients with Type II diabetes using insulin [176]. Because single s. c. or i.v. doses of pramlintide were found to slow the emptying of both solids and liquids [177, 178], as did 5 days of pramlintide t.i.d. [179], these results were attributed to that decelerative effect. However, most diabetic patients do not have enhanced but delayed emptying, so that pramlintide's effects on glycaemic control might not result from its action on the emptying function.

\section{Conclusion}

Gastric motor activity is impaired in many patients with both Type I and Type II diabetes. The resulting delayed emptying at least of solid meal components but also a rapid initial emptying of liquids could account for a mismatch between the time of absorption and the related blood-glucose increase on the one hand and the insulin or hypoglycaemic agent administered on the other and so for poor glycaemic control. Evidence indicates that the degree of ANP, rather than an increased blood-glucose concentration or gastric myopathy, is the main underlying factor. The development of therapeutic agents for the long-term treatment of impaired gastric motor function still has a long way to go.

Sources. This review is based on the personal knowledge of publications as well as on publications identified using Medline. The search terms were "diabetes mellitus", "gastric motor function", "gastric emptying", "gastroparesis", "glycaemic control", "hyperglycaemia", "hypoglycaemia", "diabetic complications", "autonomic neuropathy", "myopathy", "symptoms", "prokinetic agents", "metoclopramide", "domperidone", "cisapride", "erythromycin", "motilin", "sulpiride", "cholecystokinin", "POT II", "glucagon-like peptide-1", "amylin" and "pramlintide". The searches were last updated on 23 February 2001. Data in abstract form were included only if published not earlier than 1999.

\section{References}

1. Rundles RW (1945) Diabetic neuropathy. General review with report of 125 cases. Medicine (Baltimore) 24: 111-160

2. Hodges FJ, Rundles RW, Hanelin J (1947) Roentgenologic study of the small intestine. II. Dysfunction associated with neurologic diseases. Radiology 49: 659-673

3. Kassander P (1958) Asymptomatic gastric retention in diabetics (gastroparesis diabeticorum). Ann Intern Med 48: 797-812 
4. Loo FD, Palmer DW, Soergel KH, Kalbfleisch JH, Wood CM (1984) Gastric emptying in patients with diabetes mellitus. Gastroenterology 86: 485-494

5. Horowitz M, Harding PE, Maddox A et al. (1986) Gastric and oesophageal emptying in insulin-dependent diabetes mellitus. J Gastroenterol Hepatol 1: 97-113

6. Keshavarzian A, Iber FL, Vaeth J (1987) Gastric emptying in patients with insulin-requiring diabetes mellitus. Am J Gastroenterol 82: 29-35

7. Jones KL, Horowitz M, Wishart MJ, Maddox AF, Harding PE, Chatterton BE (1995) Relationships between gastric emptying, intragastric meal distribution and blood glucose concentrations in diabetes mellitus. J Nucl Med 36: 2220-2228

8. Merio R, Festa A, Bergmann H et al. (1997) Slow gastric emptying in type I diabetes: relation to autonomic and peripheral neuropathy, blood glucose, and glycemic control. Diabetes Care 20: 419-423

9. Lyrenäs EB, Olsson EHK, Arvidsson UC, Örn TJ, Spjutii JH (1997) Prevalence and determinants of solid and liquid gastric emptying in unstable type I diabetes. Diabetes Care 20: 413-416

10. Horowitz M, Harding PE, Maddox AF et al. (1989) Gastric and oesophageal emptying in patients with Type 2 (non-insulin-dependent) diabetes mellitus. Diabetologia 32: $151-159$

11. Caballero-Plasencia AM, Muros-Navarro MC, MartinRuiz JL et al. (1994) Gastroparesis of digestible and indigestible solids in patients with insulin-dependent diabetes mellitus or functional dyspepsia. Dig Dis Sci 39: 1409-1415

12. Chang C-S, Kao C-H, Wang Y-S, Chen G-H, Wang S-J (1996) Discrepant pattern of solid and liquid gastric emptying in Chinese patients with type II diabetes mellitus. Nucl Med Commun 17: 60-65

13. Jones KL, Horowitz M, Berry M, Wishart JM, Guha S (1997) Blood glucose concentration influences postprandial fullness in IDDM. Diabetes Care 20: 1141-1146

14. Annese V, Bassotti G, Caruso N et al. (1999) Gastrointestinal motor dysfunction, symptoms, and neuropathy in noninsulin-dependent (type 2) diabetes mellitus. J Clin Gastroenterol 29: 171-177

15. Vaisman N, Weintrob N, Blumental A, Yosefsberg Z, Vardi $P$ (1999) Gastric emptying in patients with type I diabetes mellitus. Ann NY Acad Sci 873: 506-511

16. Wright RA, Clemente R, Wathen R (1985) Diabetic gastroparesis: an abnormality of gastric emptying of solids. Am J Med Sci 289: 240-242

17. Urbain JLC, Vekemans MC, Bouillon R et al. (1993) Characterization of gastric antral motility disturbances in diabetes using a scintigraphic technique. J Nucl Med 34: 576-581

18. Troncon LEA, Rosa e Silva L, Oliveira RB, Iazigi N, Gallo L Jr, Foss MC (1998) Abnormal intragastric distribution of a liquid nutrient meal in patients with diabetes mellitus. Dig Dis Sci 43: 1421-1429

19. Schade RR, Dugas MC, Lhotsky DM, Gavaler JS, van Thiel DH (1985) Effect of metoclopramide on gastric liquid emptying in patients with diabetic gastroparesis. Dig Dis Sci 30: 10-15

20. De Caestecker JS, Ewing DJ, Tothill P, Clarke BF, Heading RC (1989) Evaluation of oral cisapride and metoclopramide in diabetic autonomic neuropathy: an eightweek double-blind crossover study. Aliment Pharmacol Ther 3: 69-81

21. Horowitz M, Maddox AF, Wishart JM, Harding PE, Chatterton BE, Shearman DJC (1991) Relationships between esophageal transit and liquid gastric emptying in diabetes mellitus. Eur J Nucl Med 18: 229-234
22. Frank JW, Saslow SB, Camilleri M, Thomforde GM, Dinneen S, Rizza RA (1995) Mechanism of accelerated gastric emptying of liquids and hyperglycemia in patients with type II diabetes mellitus. Gastroenterology 109: 755-765

23. Schwartz JG, Green GM, Guan D, McMahan CA, Phillips WT (1996) Rapid gastric emptying of a solid pancake meal in type II diabetic patients. Diabetes Care 19:468-471

24. Ahn YH, Maturu P, Steinheber FU, Goldman JM (1987) Association of diabetes mellitus with gastric bezoar formation. Arch Intern Med 147: 527-528

25. Phillips WT, Schwartz JG, McMahan CA (1992) Rapid gastric emptying of an oral glucose solution in Type 2 diabetic patients. J Nucl Med 33: 1496-1500

26. Schwartz JG, McMahan CA, Green GM, Phillips WT (1995) Gastric emptying in Mexican Americans compared to non-Hispanic whites. Dig Dis Sci 40: 624-630

27. Weytjens C, Keymeulen B, van Haleweyn C, Somers G, Bossuyt A (1998) Rapid gastric emptying of a liquid meal in long-term Type 2 diabetes mellitus. Diabet Med 15: 1022-1027

28. Jones KL, Horowitz M, Carney BI, Wishart JM, Guha S, Green L (1996) Gastric emptying in early noninsulin-dependent diabetes mellitus. J Nucl Med 37: 1643-1648

29. Samsom M, Roelofs JMM, Akkermans LMA, van BergeHenegouwen GP, Smout AJPM (1998) Proximal gastric motor activity in response to a liquid meal in Type I diabetes mellitus with autonomic neuropathy. Dig Dis Sci 43: $491-496$

30. Undeland KA, Hausken T, Aanderud S, Berstad A (1997) Lower postprandial gastric volume response in diabetic patients with vagal neuropathy. Neurogastroenterol Motil 9: $19-24$

31. Samsom M, Salet GAM, Roelofs JMM, Akkermans LMA, van Berge-Henegouwen GP, Smout AJPM (1995) Compliance of the proximal stomach and dyspeptic symptoms in patients with Type I diabetes mellitus. Dig Dis Sci 40: 2037-2042

32. Undeland KA, Hausken T, Gilja OH, Aanderud S, Berstad A (1998) Gastric meal accomodation studied by ultrasound in diabetes. Relation to vagal tone. Scand J Gastroenterol 33: 236-241

33. Lenglinger J, Bergmann H, Meghdadi S, Schneider C, Stacher G (2001) Impaired gastric emptying in diabetes mellitus related to altered intragastric meal distribution? Gastroenterology 120 [Suppl 1]:A468 (Abstract)

34. Undeland KA, Hausken T, Svebak S, Aanderud S, Berstad A (1996) Wide gastric antrum and low vagal tone in patients with diabetes mellitus Type 1 compared to patients with functional dyspepsia and healthy individuals. Dig Dis Sci 41: 9-16

35. Jebbink HJA, Bravenboer B, Akkermans LMA, van Berge-Henegouwen GP, Smout AJPM (1993) Relationship between dyspeptic symptoms and gastrointestinal motility in patients with Type 1 (insulin-dependent) diabetes mellitus. Diabetologia 36: 948-954

36. Samsom M, Jebbink RJA, Akkermans LMA, van BergeHenegouwen GP, Smout AJPM (1996) Abnormalities of antroduodenal motility in Type I diabetes. Diabetes Care 19: $21-27$

37. Achem-Karam SR, Funakoshi A, Vinik AI, Owyang C (1984) Plasma motilin concentration and interdigestive migrating motor complex in diabetic gastroparesis: effect of metoclopramide. Gastroenterology 88: 492-499

38. Camilleri M, Malagelada J-R (1984) Abnormal intestinal motility in diabetics with the gastroparesis syndrome. Eur J Clin Invest 14: 420-427 
39. Malagelada J-R, Rees WDW, Mazzotta LJ, Go VLW (1980) Gastric motor abnormalities in diabetic and postvagotomy gastroparesis: effect of metoclopramide and bethanechol. Gastroenterology 78: 286-292

40. Mearin F, Camilleri M, Malagelada J-R (1986) Pyloric dysfunction in diabetics with recurrent nausea and vomiting. Gastroenterology 90: 1919-1925

41. Jebbink HJA, Bruijs PPM, Bravenboer B, Akkermans LMA, van Berge-Henegouwen GP, Smout AJPM (1994) Gastric myoelectrical activity in patients with Type I diabetes mellitus and autonomic neuropathy. Dig Dis Sci 39: 2376-2383

42. Jebbink RJA, Samsom M, Bruijs PPM et al. (1994) Hyperglycemia induces abnormalities of gastric myoelectrical activity in patients with Type I diabetes mellitus. Gastroenterology 107: 1390-1397

43. Aylett P (1962) Gastric emptying and change of blood glucose level as affected by glucagon and insulin. Clin Sci (Colch) 22: 171-178

44. MacGregor IL, Gueller R, Watts HD, Meyer JH (1976) The effect of acute hyperglycemia on gastric emptying in man. Gastroenterology 70: 190-196

45. Morgan LM, Tredger JA, Hampton SM, French AP, Peake JC, Marks V (1988) The effect of dietary modification and hyperglycaemia on gastric emptying and gastric inhibitory polypeptide (GIP) secretion. Br J Nutr 60: 29-37

46. Øster-Jørgensen E, Pedersen SA, Larsen ML (1990) The influence of induced hyperglycaemia on gastric emptying rate in healthy humans. Scand $\mathrm{J}$ Clin Lab Invest 50: 831-836

47. Schvarcz E, Palmér M, Åman J, Horowitz M, Stridsberg M, Berne C (1997) Physiological hyperglycemia slows gastric emptying in normal subjects and patients with insulin-dependent diabetes mellitus. Gastroenterology 113: 60-66

48. Fraser RJ, Horowitz M, Maddox AF, Harding PE, Chatterton BE, Dent J (1990) Hyperglycaemia slows gastric emptying in Type 1 (insulin-dependent) diabetes mellitus. Diabetologia 33: 675-680

49. Iber FL, Parveen S, Vandrunen M et al. (1993) Relation of symptoms to impaired stomach, small bowel, and colon motility in long-standing diabetes. Dig Dis Sci 38: 45-50

50. Petrakis IE, Chalkiadakis G, Vrachossotakis N, Sciacca V, Vassilakis SJ, Xynos E (1999) Induced hyperglycemia attenuates erythromycin-induced acceleration of hypertonic liquid-phase gastric emptying in type-I diabetic patients. Dig Dis 17: 241-247

51. Samsom M, Akkermans LMA, Jebbink RJA, van Isselt H, van Berge-Henegouwen GP, Smout AJPM (1997) Gastrointestinal motor mechanisms in hyperglycaemia induced delayed gastric emptying in type I diabetes mellitus. Gut 40: 641-646

52. Rayner CK, Verhagen MA, Hebbard GS, DiMatteo AC, Doran SM, Horowitz M (2000) Proximal gastric compliance and perception of distension in type 1 diabetes mellitus: effects of hyperglycemia. Am J Gastroenterol 95: $1175-1183$

53. Schvarcz E, Palmér M, Åman J, Lindkvist B, Beckman KW (1993) Hypoglycaemia increases the gastric emptying rate in patients with Type 1 diabetes mellitus. Diabet Med 10: 660-663

54. Holzäpfel A, Festa A, Stacher-Janotta G et al. (1999) Gastric emptying in non-insulin-dependent diabetes before and after therapy readjustment: no influence of actual blood-glucose level. Diabetologia 42: 1410-1412

55. Nowak TV, Johnson CP, Kalbfleisch JH et al. (1994) Highly variable gastric emptying in patients with insulin dependent diabetes mellitus. Gut 37: 23-29
56. Ziegler D, Schadewaldt P, Pour Mirza A et al. (1996) $\left[{ }^{13} \mathrm{C}\right]$ Octanoic acid breath test for non-invasive assessment of gastric emptying in diabetic patients: validation and relationship to gastric symptoms and cardiovascular autonomic function. Diabetologia 39: 823-830

57. Horowitz M, Edelbroek MAL, Wishart JM, Straathof JW (1993) Relationship between oral glucose tolerance and gastric emptying in normal healthy subjects. Diabetologia 36: $857-862$

58. Said G, Goulin-Goeau C, Slama G, Tchobroutsky G (1992) Severe early-onset polyneuropathy in insulin-dependent diabetes mellitus. A clinical and pathological study. N Engl J Med 326: 1257-1263

59. Dyrberg T, Benn J, Sandahl Christiansen J, Hilsted J, Nerup J (1981) Prevalence of diabetic autonomic neuropathy measured by simple bedside tests. Diabetologia 20: 190-194

60. Hilsted J, Low PA (1993) Diabetic autonomic neuropathy. In: Low PA (ed) Clinical autonomic disorders: evaluation and management. Little, Brown and Company, Boston, pp 324-344

61. Sampson MJ, Wilson S, Karagiannis P, Edmonds M, Watkins PJ (1990) Progression of diabetic autonomic neuropathy over a decade in insulin-dependent diabetics. QJM 75: 635-646

62. Pirart J (1977) Diabète et complications dégénératives. Présentation d'une étude prospective portant sur 4400 cas observés entre 1947 et 1973 (en 3 parties) [Diabetes mellitus and its degenerative complications: a prospective study of 4,400 patients observed between 1947 and 1973]. Diabete Metab 3: 97-107, 173-182, 245-256

63. Dyck PJ, Zimmerman BR, Vilen TH et al. (1988) Nerve glucose, fructose, sorbitol, myo-inositol, and fiber degeneration and regeneration in diabetic neuropathy. $\mathrm{N}$ Engl J Med 319: 542-548

64. Stevens MJ (1995) Nitric oxide as a potential bridge between the metabolic and vascular hypotheses of diabetic neuropathy. Diabet Med 12: 292-295

65. Dyck PJ (1996) Nerve growth factor and diabetic neuropathy. Lancet 348: 1044-1045

66. Feldman EL, Stevens MJ, Greene DA (1997) Pathogenesis of diabetic neuropathy. Clin Neurosci 4: 365-370

67. Said G, Goulin-Goeau C, Slama G, Tchobroutsky G (1992) Severe early-onset polyneuropathy in insulin-dependent diabetes mellitus. A clinical and pathological study. N Engl J Med 326: 1257-1263

68. Said G, Slama G, Selva J (1983) Progressive centripetal degeneration of axons in small fibre diabetic polyneuropathy. Brain 106: 791-807

69. Johnson PC, Doll SC, Cromey DW (1986) Pathogenesis of diabetic neuropathy. Ann Neurol 19: 450-457

70. Dyck PJ, Lais A, Karnes JL, O’Brien P, Rizza R (1986) Fiber loss is primary and multifocal in sural nerves in diabetic polyneuropathy. Ann Neurol 19: 425-439

71. Ibrahim S, Harris ND, Radatz M et al. (1999) A new minimally invasive technique to show nerve ischaemia in diabetic neuropathy. Diabetologia 42: 737-742

72. Dyck PJ (1992) New understanding and treatment of diabetic neuropathy. N Engl J Med 326: 1287-1288

73. The Diabetes Control and Complications Trial Research Group (1993) The effect of intensive treatment of diabetes on the development and progression of long-term complications in insulin-dependent diabetes mellitus. N Engl J Med 329: 977-986

74. Watkins CC, Barrows RK, Sawa A, Snyder SH (2000) Loss of neuronal nitric oxide synthase (nNOS) in a model of diabetic gastropathy: reversal by insulin therapy and 
PDE-V inhibitors. Gastroenterology 118 [Suppl 2]:A669 (Abstract)

75. Watkins CC, Sawa A, Jaffrey S et al. (2000) Insulin restores neuronal nitric oxide expression and function that is lost in diabetic gastropathy. J Clin Invest 106: 373-384

76. Takahashi T, Nakamura K, Itoh H, Sima AA, Owyang C (1997) Impaired expression of nitric oxide synthase in the gastric myenteric plexus of spontaneously diabetic rats. Gastroenterology 113: 1535-1544

77. Ördög T, Takayama I, Cheung WKT, Ward SM, Sanders KM (2000) Remodeling of networks of interstitial cells of Cajal in a murine model of diabetic gastroparesis. Diabetes 49: 1731-1739

78. Ördög T, Ward SM, Sanders KM (2000) Interstitial cells of Cajal generate electrical slow waves in the murine stomach. J Physiol (Lond) 518: 257-269

79. He CL, Ferris CD, Soffer E, Walsh M, Szurszewski JH, Farrugia G (2000) Loss of inhibitory innervation and interstitial cells of Cajal in a patient with insulin dependent diabetes. Neurogastroenterol Motil 12: 482 (Abstract)

80. Vinik AI, Leichter SB, Pittenger GL et al. (1995) Phospholipid and glutamic acid decarboxylase autoantibodies in diabetic neuropathy. Diabetes Care 18: 1225-1232

81. Zanone MM, Peakman M, Purewal T, Watkins PJ, Vergani D (1993) Autoantibodies to nervous tissue structures are associated with autonomic neuropathy in Type 1 (insulin-dependent) diabetes mellitus. Diabetologia 36: 564-569

82. Zanone MM, Burchio S, Quadri R et al. (1998) Autonomic function and autoantibodies to autonomic nervous structures, glutamic acid decarboxylase and islet tyrosine phosphatase in adolescent patients with IDDM. J Neuroimmunol 87: 1-10

83. Ejskjaer N, Arif S, Dodds W et al. (1999) Prevalence of autoantibodies to autonomic nervous tissue structures in Type 1 diabetes mellitus. Diabetic Med 16: 544-549

84. Scarpello JMB, Barber DC, Hague RV, Cullen DR, Sladen GE (1976) Gastric emptying of solid meals in diabetics. BMJ 2: 671-673

85. Kim CH, Kennedy FP, Camilleri M, Zinsmeister AR, Ballard DJ (1991) The relationship between clinical factors and gastrointestinal dysmotility in diabetes mellitus. J Gastrointest Mot 3: 268-272

86. Buysschaert M, Moulart M, Urbain JL et al. (1987) Impaired gastric emptying in diabetic patients with cardiac autonomic neuropathy. Diabetes Care 10: 448-452

87. Lacigova S, Rusavy Z, Karova R, Jankovec Z, Zahlava J (2000) [Published in Czech, Abstract in English; Relation between cardiovascular and gastrointestinal neuropathy in diabetics]. Cas Lek Cesk 139: 79-82

88. Weck M, Ott P, Matthies K (1997) Reduced gastric emptying and mesenteric flow in IDDM with cardiac autonomic neuropathy. Acta Med Austriaca 24: 180-184

89. Werth B, Meyer-Wyss B, Spinas GA, Drewe J, Beglinger C (1992) Non-invasive assessment of gastrointestinal motility disorders in diabetic patients with and without cardiovascular signs of autonomic neuropathy. Gut 33: 1199-1203

90. Wegener M, Börsch G, Schaffstein J, Luerweg C, Leverkus F (1990) Gastrointestinal transit disorders in patients with insulin-treated diabetes mellitus. Dig Dis 8: 23-36

91. Hongo M, Okuno Y (1993) Diabetic gastropathy in patients with autonomic neuropathy. Diabet Med 10 [Suppl 2]: 79S-81S (refers to article published in Japanese by Lin YF, Hongo M, Satake K, Toyota T, Goto Y, Okuyama S (1987) [Gastric emptying of solid meals in diabetic patients]. Nippon Shokakibyo Gakkai Zasshi 84: 1-5)
92. Kawagishi T, Nishizawa Y, Okuno Y et al. (1994) Antroduodenal motility and transpyloric fluid movement in patients with diabetes studied using duplex sonography. Gastroenterology 107: 403-409

93. Buysschaert M, Donckier J, Ketelslegers J-M, Lambert AE (1985) Gastric acid and pancreatic polypeptide responses to sham feeding are impaired in diabetic subjects with autonomic neuropathy. Diabetes 34: 1181-1185

94. Feldman M, Corbett DB, Ramsey EJ, Walsh JH, Richardson CT (1979) Abnormal gastric function in longstanding, insulin-dependent diabetic patients. Gastroenterology 77: 12-17

95. Lluch I, Ascaso JF, Mora F et al. (1999) Gastroesophageal reflux in diabetes mellitus. Am J Gastroenterol 94: 919-924

96. Ziegler D, Mayer P, Muhlen H, Gries FA (1991) The natural history of somatosensory and autonomic nerve dysfunction in relation to glycaemic control during the first 5 years after diagnosis of Type 1 (insulin-dependent) diabetes mellitus. Diabetologia 34: 822-829

97. Töyry JP, Niskanen LK, Mäntysaari MJ, Länsimies EA, Uusitupa MIJ (1996) Occurrence, predictors, and clinical significance of autonomic neuropathy in NIDDM. Tenyear follow-up from the diagnosis. Diabetes 45: 308-315

98. Töyry JP, Partanen JVS, Niskanen LK, Länsimies EA, Uusitupa MIJ (1997) Divergent development of autonomic and peripheral somatic neuropathies in NIDDM. Diabetologia 40: 953-958

99. Levitt NS, Stansberry KB, Wynchank S, Vinik AI (1996) The natural progression of autonomic neuropathy and autonomic function tests in a cohort of people with IDDM. Diabetes Care 19: 751-754

100. Duchen LW, Anjorin A, Watkins PJ, Mackay JD (1980) Pathology of autonomic neuropathy in diabetes mellitus. Ann Intern Med 92: 301-303

101. Yoshida MM, Schuffler MD, Sumi SM (1988) There are no morphologic abnormalities of the gastric wall or abdominal vagus in patients with diabetic gastroparesis. Gastroenterology 94: 907-914

102. Takahashi T, Kojima Y, Tsunoda Y et al. (1996) Impaired intracellular signal transduction in gastric smooth muscle of diabetic BB/W rats. Am J Physiol 270: G411-G417

103. Ejskjaer NT, Bradley JL, Buxton-Thomas M et al. (1999) Novel surgical treatment and gastric pathology in diabetic gastroparesis. Diabet Med 16: 488-495

104. Rathmann W, Enck P, Frieling T, Gries FA (1991) Visceral afferent neuropathy in diabetic gastroparesis. Diabetes Care 14: 1086-1089

105. Janatuinen E, Pikkarainen P, Laakso M, Pyörälä K (1993) Gastrointestinal symptoms in middle-aged diabetic patients. Scand J Gastroenterol 28: 427-432

106. Maleki D, Locke GR $3^{\text {rd }}$, Camilleri M et al. (2000) Gastrointestinal tract symptoms among persons with diabetes mellitus in the community. Arch Intern Med 160: 2808-2816

107. Schvarcz E, Palmér M, Ingberg CM, Åman J, Berne C (1996) Increased prevalence of upper gastrointestinal symptoms in long-term type 1 diabetes mellitus. Diabet Med 13: 478-481

108. Spangeus A, El-Salhy M, Suhr O, Eriksson J, Lithner F (1999) Prevalence of gastrointestinal symptoms in young and middle-aged diabetic patients. Scand J Gastroenterol 34: 1196-1202

109. Ricci JA, Siddique R, Stewart WF, Sandler RS, Sloan S, Farup CE (2000) Upper gastrointestinal symptoms in a U.S. national sample of adults with diabetes. Scand J Gastroenterol 35: 152-159 
110. Meyer JH, Elashoff J, Porter-Fink V, Dressman J, Amidon GL (1988) Human postprandial gastric emptying of 1-3-millimeter spheres. Gastroenterology 94: 1315-1325

111. Feldman M, Smith HJ, Simon TR (1984) Gastric emptying of solid radiopaque markers: studies in healthy subjects and diabetic patients. Gastroenterology 87: 895-902

112. Hunt JN, Smith JL, Jiang CL (1985) Effect of meal volume and energy density on the gastric emptying of carbohydrates. Gastroenterology 89: 1326-1330

113. Lin HC, Doty JE, Reedy TJ, Meyer JH (1989) Inhibition of gastric emptying by glucose depends on length of intestine exposed to nutrient. Am J Physiol 256: G404-G411

114. Akkermans LMA, Jacobs F, Oei Hong Yoe, Roelofs JMM, Wittebol P (1980) A non-invasive method to quantify antral contractily activity in man and dog (a preliminary report). In: Christensen J (ed) Gastrointestinal motility. Raven Press, New York, pp 195-202

115. Stacher G, Bergmann H, Wiesnagrotzki S et al. (1987) Intravenous cisapride accelerates delayed gastric emptying and increases antral contraction amplitude in patients with primary anorexia nervosa. Gastroenterology 92: 1000-1006

116. van den Maegdenbergh V, Vandecruys A, Siegel JA, De Roo MC, Urbain J-L (1990) Visualization of the gastric mechanical systole using a new scintigraphic technique. J Nucl Med Technol 18: 248-251

117. Bergmann H, Minear G, Kugi A, Stacher G (1994) Evaluation of gastric antral motility in four dimensions. SPIE 2359: 724-729

118. Ham HR, Muls V, Cadière G-B, Froideville J-L, Urbain D (1995) A radionuclide study of regional gastric motility. Nucl Med Commun 16: 827-833

119. Ghoos YV, Maes BD, Geypens BJ et al. (1993) Measurement of gastric emptying rate of solids by means of a carbon-labeled octanoic acid breath test. Gastroenterology 104: 1640-1647

120. Bolondi L, Bortolotti M, Santi V, Calletti T, Gaiani S, Labò G (1985) Measurement of gastric emptying time by real-time ultrasonography. Gastroenterology 89: 752-759

121. Darwiche G, Almer LO, Björgell O, Cederholm C, Nilsson P (1999) Measurement of gastric emptying by standardized real-time ultrasonography in healthy subjects and diabetic patients. J Ultrasound Med 18: 673-682

122. Mansi C, Savarino V, Vigneri S et al. (1995) Gastrokinetic effects of levosulpiride in dyspeptic patients with diabetic gastroparesis. Am J Gastroenterol 90: 1989-1993

123. Melga P, Mansi C, Ciuchi E, Giusti R, Sciabà L, Prando R (1997) Chronic administration of levosulpiride and glycemic control in IDDM patients with gastroparesis. Diabetes Care 20: 55-58

124. Benini L, Sembenini C, Heading RC et al. (1999) Simultaneous measurement of gastric emptying of a solid meal by ultrasound and by scintigraphy. Am J Gastroenterol 94: 2861-2865

125. Cappello G, Malatesta MG, Ferri A et al. (2000) Gastric emptying of a solid-liquid meal measured with ${ }^{13} \mathrm{C}$ octanoic acid breath test and real-time ultrasonography: a comparative study. Am J Gastroenterol 95: 3097-3100

126. Holt S, Cervantes J, Wilkinson AA, Wallace JHK (1986) Measurement of gastric emptying rate in humans by realtime ultrasound. Gastroenterology 90: 918-923

127. Gilja OH, Hausken T, Wilhelmsen I, Berstad A (1996) Impaired accomodation of proximal stomach to a meal in functional dyspepsia. Dig Dis Sci 41: 689-696

128. Gilja OH, Detmer PR, Jong JM et al. (1997) Intragastric distribution and gastric emptying assessed by three-dimensional ultrasonography. Gastroenterology 113: 38-49
129. Gilbey SG, Watkins PJ (1987) Measurement by epigastric impedance of gastric emptying in diabetic autonomic neuropathy. Diabet Med 4: 122-126

130. Schwizer W, Maecke H, Fried M (1992) Measurement of gastric emptying by magnetic resonance imaging in humans. Gastroenterology 103: 369-376

131. Vinik AI, Holland MT, Le Beau JM, Liuzzi FJ, Stansberry KB, Colen LB (1992) Diabetic neuropathies. Diabetes Care 15: 1926-1975

132. Gentry P, Miller PF (1989) Nutritional considerations in a patient with gastroparesis. Diabetes Educ 15: 374-376

133. Anderson JW, Zeigler JA, Deakins DA et al. (1991) Metabolic effects of high-carbohydrate, high-fiber diets for insulin-dependent diabetic individuals. Am J Clin Nutr 54: 936-943

134. Groop PH, Aro A, Stenman S, Groop L (1993) Long-term effects of guar gum in subjects with non-insulin-dependent diabetes mellitus. Am J Clin Nutr 58: 513-518

135. Chandalia M, Garg A, Lütjohann D, von Bergmann K, Grundy SM, Brinkley LJ (2000) Beneficial effects of high fiber intake in patients with type 2 diabetes mellitus. N Engl J Med 342: 1392-1398

136. Torsdottir I, Alpsten M, Andersson H, Einarsson S (1989) Dietary guar gum effects on postprandial blood glucose, insulin and hydroxyproline in humans. J Nutr 119: 1925-1931

137. Benini L, Castellani G, Brighenti F (1995) Gastric emptying of a solid meal is accelerated by the removal of dietary fibre naturally present in food. Gut 36: 825-830

138. Ray TK, Mansell KM, Knight LC, Malmud LS, Owen OE, Boden G (1983) Long-term effects of dietary fiber on glucose tolerance and gastric emptying in noninsulin-dependent diabetic patients. Am J Clin Nutr 37: 376-381

139. Torsdottir I, Alpsten M, Holm G, Sandberg A-S, Tölli J (1991) A small dose of soluble alginate-fiber affects postprandial glycemia and gastric emptying in humans with diabetes. J Nutr 121: 795-799

140. Vincent RM, Roberts A, Frier M, Perkins AC, MacDonald IA, Spiller RC (1995) Effect of bran particle size on gastric emptying and small bowel transit in humans: a scintigraphic study. Gut 37: 216-219

141. McIntyre A, Vincent RM, Perkins AC, Spiller RC (1997) Effect of bran, ispaghula, and inert plastic particles on gastric emptying and small bowel transit in humans: the role of physical factors. Gut 40: 223-227

142. Tonini M, Rizzi CA, Manzo L, Onori L (1991) Novel enteric $5-\mathrm{HT}_{4}$ receptors and gastrointestinal prokinetic action. Pharmacol Res 24: 5-14

143. Briejer MR, Akkermans LMA, Schuurkes JAJ (1995) Gastrointestinal prokinetic benzamides: the pharmacology underlying stimulation of motility. Pharmacol Rev 47: 631-651

144. Ricci DA, Saltzman MB, Meyer C, Callachan C, McCallum RW (1985) Effect of metoclopramide in diabetic gastroparesis. J Clin Gastroenterol 7: 25-32

145. Feldman M, Smith HJ (1987) Effect of cisapride on gastric emptying of indigestible solids in patients with gastroparesis diabeticorum. A comparison with metoclopramide and placebo. Gastroenterology 92: 171-174

146. Snape WJ Jr, Battle WM, Schwartz SS, Braunstein SN, Goldstein HA, Alavi A (1982) Metoclopramide to treat gastroparesis due to diabetes mellitus: a double-blind, controlled trial. Ann Intern Med 96: 444-446

147. Barone JA (1999) Domperidone: a peripherally acting dopamine2-receptor antagonist. Ann Pharmacother 33: 429-440 
148. Heer M, Müller-Duysing W, Benes I et al. (1983) Diabetic gastroparesis: treatment with domperidone - a doubleblind, placebo-controlled trial. Digestion 27: 214-217

149. Horowitz M, Harding PE, Chatterton BE, Collins PJ, Shearman DJC (1985) Acute and chronic effects of domperidone on gastric emptying in diabetic autonomic neuropathy. Dig Dis Sci 30: 1-9

150. Koch KL, Stern RM, Stewart WR, Vasey MW (1989) Gastric emptying and gastric myoelectrical activity in patients with diabetic gastroparesis: effect of long-term domperidone treatment. Am J Gastroenterol 84: 1069-1075

151. Silvers D, Kipnes M, Broadstone Vet al. (1998) Domperidone in the management of symptoms of diabetic gastroparesis: efficacy, tolerability, and quality-of-life outcomes in a multicenter controlled trial. DOM-USA-5 Study Group. Clin Ther 20: 438-453

152. Rossi F, Forgione A (1995) Pharmacotoxicological aspects of levosulpiride. Pharmacol Res 31: 81-94

153. McHugh S, Lico S, Diamant NE (1992) Cisapride vs metoclopramide. An acute study in diabetic gastroparesis. Dig Dis Sci 37: 997-1001

154. Abell TL, Camilleri M, DiMagno EP, Hench VS, Zinsmeister AR, Malagelada J-R (1991) Long-term efficacy of oral cisapride in symptomatic upper gut dysmotility. Dig Dis Sci 36: 616-620

155. Kawagishi T, Nishizawa Y, Okuno Y, Sekiya K, Morii H (1993) Effect of cisapride on gastric emptying of indigestible solids and plasma motilin concentration in diabetic autonomic neuropathy. Am J Gastroenterol 88: 933-938

156. Horowitz M, Maddox A, Harding PE et al. (1987) Effect of cisapride on gastric and esophageal emptying in insulin-dependent diabetes mellitus. Gastroenterology 92: 1899-1907

157. Dutta U, Padhy AK, Ahuja V, Sharma MP (1999) Double blind controlled trial of effect of cisapride on gastric emptying in diabetics. Trop Gastroenterol 20: 116-119

158. Havelund T, Øster-Jørgensen E, Eshøj O, Larsen ML, Lauritsen K (1987) Effects of cisapride on gastroparesis in patients with insulin-dependent diabetes mellitus. A double-blind controlled trial. Acta Med Scand 222: 339-343

159. Stacher G, Schernthaner G, Francesconi M et al. (1999) Cisapride versus placebo for 8 weeks on glycemic control and gastric emptying in insulin-dependent diabetes: a double-blind cross-over trial. J Clin Endocrinol Metab 84: 2357-2362

160. Peeters T, Matthijs G, Depoortere I, Cachet T, Hoogmartens J, Vantrappen G (1989) Erythromycin is a motilin receptor agonist. Am J Physiol 257: G470-G474

161. Janssens J, Peeters TL, Vantrappen G et al. (1990) Improvement of gastric emptying in diabetic gastroparesis by erythromycin. Preliminary studies. N Engl J Med 322: 1028-1031

162. Urbain J-L, Vantrappen G, Janssens J, van Cutsem E, Peeters T, de Roo M (1990) Intravenous erythromycin dramatically accelerates gastric emptying in gastroparesis diabeticorum and normals and abolishes the emptying discrimination between solids and liquids. J Nucl Med 31: 1490-1493

163. Desautels SG, Hutson WR, Christian PE, Moore JG, Datz FL (1995) Gastric emptying response to variable oral erythromycin dosing in diabetic gastroparesis. Dig Dis Sci 40: 141-146

164. Samsom M, Jebbink RJA, Akkermans LMA, Bravenboer B, van Berge-Henegouwen GP, Smout AJPM (1997) Effects of oral erythromycin on fasting and postprandial antroduodenal motility in patients with Type I diabetes, measured with an ambulatory manometric technique. Diabetes Care 20: 129-134

165. Phillips WT, Schwartz JG, McMahan CA (1993) Reduced postprandial blood glucose levels in recently diagnosed non-insulin-dependent diabetics secondary to pharmacologically induced delayed gastric emptying. Dig Dis Sci 38: $51-58$

166. Liddle RA, Rushakoff RJ, Morita ET, Beccaria L, Carter JD, Goldfine ID (1988) Physiological role for cholecystokinin in reducing postprandial hyperglycemia in humans. J Clin Invest 81: 1675-1681

167. Schwartz JG, Guan D, Green GM, Phillips WT (1994) Treatment with an oral proteinase inhibitor slows gastric emptying and acutely reduces glucose and insulin levels after a liquid meal in type II diabetic patients. Diabetes Care 17: 255-262

168. Ahren B (1998) Glucagon-like peptide-1 (GLP-1): a gut hormone of potential interest in the treatment of diabetes. Bioessays 20: 642-651

169. Nauck MA, Niedereichholz U, Ettler R et al. (1997) Glucagon-like peptide 1 inhibition of gastric emptying outweighs its insulinotropic effects in healthy humans. Am J Physiol 273: E981-E988

170. Willms B, Werner J, Holst JJ, Orskov C, Creutzfeldt W, Nauck MA (1996) Gastric emptying, glucose responses, and insulin secretion after a liquid test meal: effects of exogenous glucagon-like peptide-1 (GLP-1)-(7-36) amide in type 2 (noninsulin-dependent) diabetic patients. J Clin Endocrinol Metab 81: 327-332

171. Todd JF, Edwards CM, Ghatei MA, Mather HM, Bloom SR (1998) Subcutaneous glucagon-like peptide-1 improves postprandial glycaemic control over a 3-week period in patients with early type 2 diabetes. Clin Sci (Colch) 95: 325-329

172. Ludvik B, Kautzky-Willer A, Prager R, Thomaseth K, Pacini G (1997) Amylin: history and overview. Diabetic Med 14 [Suppl 2]: S9-S13

173. Kolterman OG, Schwartz S, Corder C et al. (1996) Effect of 14 days' subcutaneous administration of the human amylin analogue, pramlintide (AC137), on an intravenous insulin challenge and response to a standard liquid meal in patients with IDDM. Diabetologia 39: 492-499

174. Thompson RG, Peterson J, Gottlieb A, Mullane J (1997) Effects of pramlintide, an analog of human amylin, on plasma glucose profiles in patients with IDDM: results of a multicenter trial. Diabetes 46: 632-636

175. Kong M-F, King P, Macdonald IA et al. (1997) Infusion of pramlintide, a human amylin analogue, delays gastric emptying in men with IDDM. Diabetologia 40: $82-88$

176. Kong MF, Stubbs TA, King P et al. (1998) The effect of single doses of pramlintide on gastric emptying of two meals in men with IDDM. Diabetologia 41: 577-583

177. Samsom M, Szarka LA, Camilleri M, Vella A, Zinsmeister AR, Rizza RA (2000) Pramlintide, an amylin analog, selectively delays gastric emptying: potential role of vagal inhibition. Am J Physiol 278: G946-G951

178. Thompson RG, Pearson L, Kolterman OG (1997) Effects of 4 weeks' administration of pramlintide, a human amylin analogue, on glycaemia control in patients with IDDM: effects on plasma glucose profiles and serum fructosamine concentrations. Diabetologia 40: 1278-1285

179. Thompson RG, Pearson L, Schoenfeld SL, Kolterman OG (1998) Pramlintide, a synthetic analog of human amylin, improves the metabolic profile of patients with type 2 diabetes using insulin. The Pramlintide in Type 2 Diabetes Group. Diabetes Care 21: 987-993 